\title{
ABCA5 Gene
}

National Cancer Institute

\section{Source}

National Cancer Institute. ABCA5 Gene. NCI Thesaurus. Code C103876.

This gene is involved in both ATP binding and catabolism. 